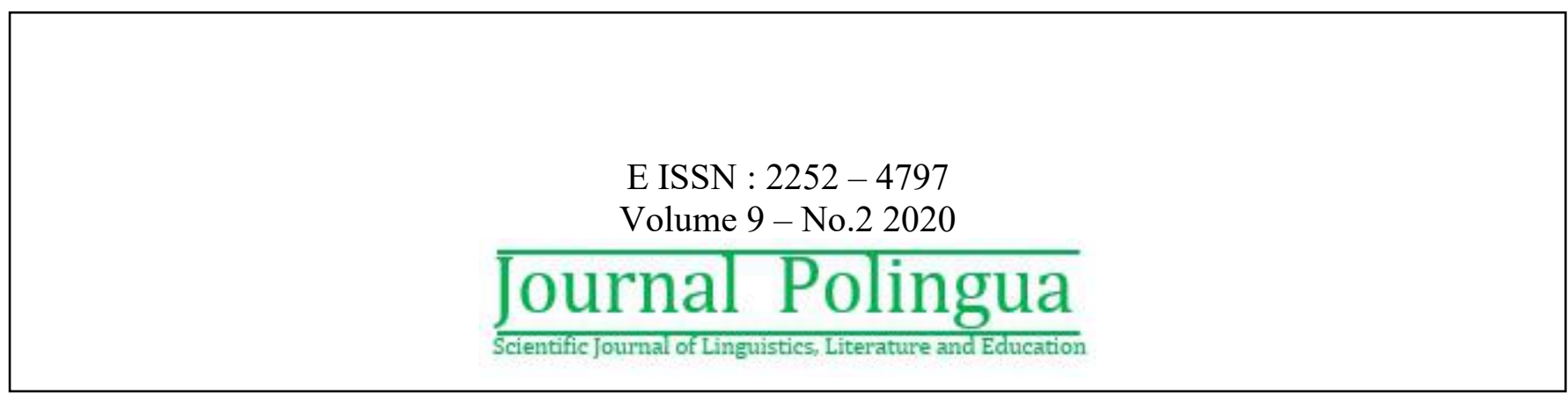

\title{
Ecological Crisis And Exploitation Of Women in Margaret Atwood's Surfacing
}

\author{
Riyani Vadilla ${ }^{1 *}$, Ferdinal $^{2}$, Silvia Rosa ${ }^{3}$ \\ ${ }^{123}$ Literature Study Program, Andalas University, Limau Manis, Padang , 25166, Padang \\ E-mail:1,vadillariyani@gmail.com,2fnu_ferdinal@yahoo.com, ${ }^{3}$ sylvie_rosha@ymail.com
}

\begin{abstract}
Ecological crisis in literature occurs where authors expose that people have degraded the ecosystem and exploited women. These issues occur in various parts of the world, and the writers claim them to be true in literary work. This descriptive study aims to examine the ecological crisis and the exploitation of women found in the novel Surfacing by Margaret Atwood by using the ecofeminism theory of Vandana Shiva and Maria Mies. This research uses three variables: 1. Reduction of women's uterus, 2. Maldevelopment, 3. Exploitation. This research is library research. To see the representation of colors, researchers used the theory of ecofeminism introduced by Vandana Shiva and Maria Mies. The results showed an ecological crisis and exploitation of women found in the novel Surfacing, namely (1) interference of modern science and technology causes the reduction of the womb of women, (2) pornography of women and exploitation of animals for commercial purposes, (3) maldevelopment and illegal logging for various interests industry
\end{abstract}

Keywords - ecofeminism, capitalist patriarchy, woman exploitation, Surfacing, ecofeminism, ecological crisis

\section{INTRODUCTION}

The problem of ecological crisis and exploitation of women today is a phenomenon that is both troubling and worrying and at the same time seizes the attention of many parties, both the general public and activists who care about women and the environment because it has caused significant losses in terms of women and nature who are victims. Humans who should live side by side with nature exploit nature and women. The environment and women's fate are increasingly deteriorating due to patriarchal systems and capitalism developed in developed countries such as the United States, Canada and developing countries such as India, Indonesia, and others. Technology and science develop rapidly and increase the capitalist patriarchy gap that dichotomizes man-nature, man-woman, and culture-nature. The presence of technology and science then leads to reductionist violence against women and nature. Women are not involved in nature exploration, which is controlled by the state and private companies. Besides, women's contribution to utilizing nature to meet their daily needs is also underestimated and has no value contributing to the state. The exploitation of women and nature has not escaped the observations of writers in the 1970s, such as Margaret Atwood, Barbara Kingsolver, Anindita S. Thayf, Doris Lessing, Carol Warner, Alice Munro, and
Jeanette Winterson. These writers are a series of names of writers who concern about what happens to women and nature.

In line with violence against women and nature, this article will discuss the ecological crisis and exploitation of women in Surfacing by Margaret Atwood, published in 1983. Surfacing tells the main character's journey, her lover Joe and two friends named Anna and David to their hometown in northern Quebec, Canada, to trace the main character's missing father's whereabouts. The issue of exploitation of women has been mentioned earlier in the research of Bhalla ${ }^{[9]}$, Khan ${ }^{[10]}$, Koukhaei and Afrougheh ${ }^{[11]}$, and Monika ${ }^{[2]}$. Bhalla ${ }^{[9]}$, for example, argues that power and dominance oppress both the feminine and natural worlds. In the story, the protagonist thinks she is aware of the gap between her natural self and herself based on artificial construction when she enters nature. Bhalla states that the protagonist is an eco-feminist who is aware of women's victimization when she associates nature and feels the earth is her real home where everything is related, full of diversity, and complex. Bhalla sees that both power and domination oppress the natural world and the feminine world. He sees the protagonist makes a psychological journey to get her identity and roots. She symbolizes all that is abused and exploited because of their powerlessness. According to Bhalla $^{[9]}$, Surfacing reveals that men destroy women and nature, and the relationship between nature and men is exploitation. The protagonist has sympathy for dying white 
birches and found a reflection of what happened to her and nature. She even releases frogs that will be the fish's bait. Bhalla also sees the relationship of David dan Anna as a relationship that is imbalanced and full of tensions. Anna is naturalized like an animal when being asked to pose naked with a dead heron. Bhalla sees the camera as a phallic symbol to show men's power over women. He even mocked Beaver, Canada's national emblem, which indicates three things; fur trading commodities that attracted European traders, colonizers, and American capital; Second, the reduction of pornography from women, and third, the U.S. and Britain colonized Canada. Bhalla also concluded that language, characters, and events in the novel reflect a world that dominates and oppresses both nature and women, where women lose their strength to survive and passively want to abort their babies. The aborted babies are not considered and equated with animals. Men exploit women for their needs, including controlling the birth process of babies with reproductive technology. It deprived women's ability to feel the rhythm of their bodies. After the abortion, the protagonists care more about nature and want to victimize animals and behave like animals. Bhalla reveals that the protagonist realizes her victimization and takes revenge for exploiting her with her ex-lover. She uses Joe to get pregnant but does not want to marry Joe. According to Bhalla, the protagonist does not want women to dominate but wants harmony between men and women.

On the other hand, Khan ${ }^{[10]}$, in a dissertation entitled "The Power and Promise of Ecofeminism: A Study of Selected Novels of Margaret Atwood and Alice Walker" revealed that both patriarchy and colonialism had become Canada's collective unconscious and became a convincing metaphor for exploitation feminine and natural. According to Khan ${ }^{[10]}$, what oppresses the feminine world and nature is power and dominance, including the feminine principles such as the mother earth, body, emotions, and irrationality, while the masculine principle appears in rationality, culture, and logic. The narrator considers herself comparable to the natural world and refuses to be in a patriarchal trap that destroys her. Surfacing raises the price of femininity but, on the one hand, dramatizes the desire to break dualism in the Atwood style. Victimization of women in patriarchal societies has become a metaphor for violence against nature through civilization. Khan also concluded that Surfacing shows women as nature is an essential part of the problem of ecofeminism. Women as nature do not have the glory of a Gaia-Esque identity but rather make it Other. Atwood questions the politics of power that still exists and makes the narrator raise conquest and victimization. According to him, Atwood failed to conjure up a possible dual role because the masculine community did not allow him to play that role. The narrator psychologically turns into an animal and questions whether he changes or recognizes himself. Atwood underlined the land's exploitation and featured the narrator, who secretly releases bait into the lake while David is fishing. Also, Khan revealed that technology had alienated people from animistic pastoral spirituality that has preserved human culture for centuries.

Besides Khan and Bhalla, there are also Koukhaei and Afrougheh ${ }^{[11]}$, who analyze Surfacing using Val Plumwood's theory and focus on the ecological crisis and women's life situation, nature, and animals. According to Koukhaei and
Afrougheh in Surfacing, there is a dualism of male/female, cultural/ natural, subject/object, human/natural, and human/animal. They reveal that five features of dualism reflect oppression in western culture where (1) women and nature are minimal to domestic work, seen as land reproductive after marriage, and uncomfortable steady gaze by men to women; (2) man hyper-separated themselves from women and nature and acts as the superior one; (3) there is the incorporation of the relational definition of women and nature where women perceive themselves as man's need projection as well become their powerless subordinate that could be manipulated easily in that biner sight of men and women; (4) there is an objectification of women and nature in service of males where men devalue women and nature and objectify them as sexual object and object of violent activity and resources that could be exploited and objectified; and (5) there are stereotype and pattern of domination of nature and women where women's reproductive power; their feminity is stereotyped; the landscaped was raped.

On the other hand, Monika ${ }^{[12]}$ highlights the suppression of women in Surfacing. Monika reveals the protagonist's inner conflict and her quest for survival and landscape degradation and its consequence. The protagonist, who has no name, feels like a victim and a member of a patriarchal society and the party responsible for saving the world. Monika described the protagonist as cut off from language, culture, family history, and a missing father. To seek, discover, and reconstruct his identity, the protagonist needs recreation.

Monika argues that Surfacing provides a unique view of both nature and women's oppressed conditions in which women and men are in opposition to one another. The protagonist feels incompatible with the pressures of modern life and civilization and feels guilty when fishing with his friends for hurting nature. This character also despises what Americans do to nature and compares it to dogs. They repeatedly ravage and rob landscapes and destroy the interrelationships between humans and nature. Monika sees her friends and her lover as a symbol of consumer-oriented life, which she denies.

Monika also sees that Atwood highlights human beings who worship Jesus Christ, but they still sacrifice the animal for food and exploit birds and fish. Women are not free, independent, jobless, and inequal in concrete ways. They are the second-class citizens, who should remain at home only, and as sexual objects to fulfill men's physical, domestic and sexual needs in which men are the sexual aggressors and women as passive victims. Initially, the protagonist cannot defend Anna from David's mistreatment of Anna until the protagonist destroys the film that records the naked Anna. The protagonist's action shows or symbolizes a rejection of patriarchy and women's rejection of patriarchy victims.

Monika then declares that Anna is a victim of patriarchy, and the protagonist is not. The protagonist denies subordination. Even though she experiences a sort of oppression, she refuses to be a victim. She fights alone by journeying to the wilderness. Monika argues that the protagonist decides to be a natural woman who runs her life naturally. The protagonist is tired of civilization and wants to get rid of the burden of civilization.

Previous studies of Surfacing have not yet highlighted the exploitation of women in the reproduction side, which is the 
reduction of the womb of women and the ecological crisis issue which is maldevelopment caused by the advancement of science, the interference of capitalist patriarchy in the field of reproduction, illegal logging, pornography, maldevelopment and exploitation of animal. This research can help uncover those things in Surfacing. The reduction of women's womb and the maldevelopment by capitalist patriarchy found in the novel will help awaken the reader that the capitalist patriarchy's domination has exploited women and nature. The practice gains commercial interests: illegal logging, pornography, and exploitation of animals. This research also broadens and sharpens the previous studies' findings, which claim that women's exploitation reduces women's womb.

What is conspicuous and novel in this novel is the use of the first perssson narrator. Atwood uses the narrator to reject capitalist patriarchy's exploitation in the form of maldevelopment in North Quebec. The reduction of women's womb, maldevelopment, pornography of women and exploitation of animals for the commercial benefit, and logging of trees for the benefit of various industries is a symbol of planting a development paradigm that seeks to destroy the well-ordered order between humans and nature in running life.

\section{METHOD}

This research applies a qualitative descriptive method. The primary data were taken from the novel, and they were analyzed through ecofeminism by Shiva and Mies. This theory focuses more on women's relationships (in the concept of gender itself) with nature. Shiva ${ }^{[20]}$ highlights the effort of the Chipko movement related to the destruction of the forest. For Chipko, "Movements by rural women to protect forests or rivers have always been rooted in protecting their agricultural base: for the Chipko women, forests provide food, and the movement to protect them is a movement to provide food to their families, their cattle (which they perceive as an extension of the human family) and their soils". Shiva and Mies ${ }^{[8]}$ argued that the phenomenon of female fertility was seen as a disease, caused women to become 'sick because of their fertility' and make them rely on innovation, technology, and medical treatment.

Data analysis techniques in this study are as the following steps; (1) read Margaret Atwood's Surfacing novel heuristically and hermeneutically, (2) determine the main characters and side characters concerning the perspective (way of looking) something predominantly female characters and male characters toward women and nature, (3) analyze and classify exploitation of women and ecological crisis, (4) describe the exploitation of women and ecological crisis, (5) then finally, conclude the results of an analysis of the exploitation of women and ecological crisis.

\section{RESULTS AND DISCUSSION}

Previous studies on Surfacing claimed that women's ecological crisis and exploitation were violence against nature and women. All aspects of nature and women are exploited, stereotyped, and objectified by men. For example, people cut off trees; exploited frogs and fish through fishing activity; an American shot a heron; and a film crew exploited and treated women's bodies as sexual objects to fulfill men's needs by fooling women with fake marriage, domestication of women, pornography. However, the studies do not discuss the reduction of women's womb by the presence of modern technology and science, porn sight that makes patriarchy capitalist exploit women, exploiting nature for commercial interest, and development that destroys nature by patriarchy capitalist. Bhalla, just in a glance, reveals that men with their reproductive technology control childbirth that make women unable to feel their body rhythm but not specifically discussed the womb of women that are reducted by modern technology and science. Meanwhile, Khan ${ }^{[10]}$ links technology with animistic pastoral spirituality that alienated people. However, Bhalla $^{[9]}$, Monika ${ }^{[12]}$, Koukhaei and Afrougheh ${ }^{[11]}$, and Khan ${ }^{[10]}$ do not discuss the maldevelopment aspect by the capitalist patriarchy.

There is the exploitation of women and nature in Surfacing that has not been mentioned widely and sharply by previous researchers, namely the reduction of the womb of women with the presence of technology and science, pornography of women and exploitation of animals for the commercial benefit, and maldevelopment and logging of trees for the benefit of various industries.

\section{A. The Reduction of The Womb of Women With The Presence Of Modern Technology And Science}

Surfacing describes women and nature as an object and 'the other' and exploited by capitalist patriarchy. Surfacing reveals a reduction of women's uterus in the form of abortion and contraceptive pill. The reduction of women's uterus is the development of reproductive technology besides biotechnology and genetic manipulation. Mies and Shiva ${ }^{[16]}$ state that the three developments make women very aware of gender bias from technology and science, whereas the science paradigm has an anti-nature characteristic, patriarchal, colonial, and has aimed to distance women from their generative power, likewise nature's productive power. Women's uterus, a private right of women, then intervented by modern knowledge science, is reductionist in abortion. Abortion is a product that capitalist patriarchy creates to control human birth with a reductionist method and exploits women as consumers. Meanwhile, women with all of their traditional knowledge do not need that kind of bad treatment because they have feminine principles (Prakriti) that make them do not want to hurt another creature or, in general, nature.

In the reductionist of women's uterus, there is also an indication of sexism by capitalist patriarchy. In reductionist women's uterus, sexism appears when the first-person narrator "I" tells about her awful experience when medical workers do an abortion on her. Those medical tools should not be used on her body and make her feel traumatized. That thing indicates that women's uterus, a private right of women in Surfacing, is violated. Shiva and Mies ${ }^{[17]}$ state that women's uterus has become a powerless form and women's passivity is manipulated in line with their unknowability, as Atwood ${ }^{[2]}$ declares in this following quitation :

"...they shut you into a hospital, they shave the hair off you and tie your hands down, and they 
do not let you see, they do not want you to understand, they want you to believe it is their power, not yours. They stick needles into you so you will not hear anything, you might as well be a dead pig, your legs are up in the metal frame, they bend over you, technicians, mechanics, butchers, students clumsy or sniggering practicing on your body, they take the baby out with a fork like a pickle out of a pickle jar. After that, they fill your veins up with red plastic. I saw it running through the tube. I will not let them do that to me again"

The participation of technology in the quotation above shows that women became the victim of bias of gender by the modern knowledge that is developed by capitalist patriarchy in masculine society and treated as land, mountain, sea, forest that they have exploited.

Atwood presents the reductionist women's uterus in the form of abortion only and the contraceptive pill. The presence of a contraceptive pill makes women alienated by the modern knowledge that makes women become the object of an experiment and reduce their reproductive capacity. The reduction of women's uterus in Surfacing shows that women are not humans, individuals, and as a group inseparable with nature but as the object of technology is in reproduction. Atwood employs Anna to reveal the reduction of women's uterus. Through the eyes of the narrator, Atwood ${ }^{[3]}$ uses an act where David asks the narrator to consume that pill and says that the contraceptive pill is the same as aspirin meanwhile actually that pill has a side effect, as follows:

"You on the pill?" Anna asks suddenly.

I looked at her, startled. It took me a minute, why did she want to know? That was what they used to call a personal question.

"Not any more," I said.

"Me neither," she said glumly.

...

Anna nodded; she was tugging at the weeds as though she was pulling hair. "Bastards," she said, "they're so smart, you think they'd be able to come up with something that'd work without killing you. David wants me to go back on, he says it's no worse for you than aspirin, but next time it could be the heart or something. I mean,

I'm not taking those kinds of chances.'

It shows that women's uterus is reduced by reproduction technology, so that capitalist patriarchy controls women's fertility and does not care about the pill's effect that they ask women to consume. Klein in Shiva and Mies ${ }^{[18]}$ tells that there are women who report that they experience infertility as the impact of contraceptive methods that worsen like Dakon Shield, I.U.D., and treatment without care. The reduction of women's uterus is a form of domination carried out by capitalist patriarchy to oppress women. Practically, capitalist patriarchy applies men/women dualism where women become the subordinate. That way of think that dichotomized women and nature that is Atwood reveals in Surfacing novel.

In this case, modern knowledge nowadays is controlled by white men scientists. When I character tells her traumatic experience deals with abortion, it indicates that Atwood persuades the reader to realize that there is the reduction of women's uterus carried out by capitalist patriarchy by using modern knowledge that is universal and patriarchal as well as oppresses women.

\section{B. Pornography against Women and Exploitation of Animal for Comercial Interest}

Pornography issue against women and exploitation of animal in Surfacing novel is described clearly by Atwood ${ }^{[4]}$ when David, character that represents capitalist patriarchy ask her wife, Anna to take off her clothing for video shooting for Random Samples film, as the following quotation :

"Come on, take it off," David said; his lighthumor voice.

"I wasn't bothering you." Anna was muted, avoiding.

"It won't hurt you, we need a naked lady."

"What the hell for?" Anna was peevish now, her veiled head upturned; her eyes would be squinting.

"Random Samples," David said patiently..." You'll go in beside the dead bird, it's your chance for stardom, you've always wanted fame. You'll get to be on Educational T.V." he added as though it was a special bribe.

In the quotation above, David's character reflects capitalist patriarchy, who dominates and exploits women. His act represents capitalist patriarchy's act, who pays attention to the Cartesian concept. Shiva ${ }^{[14]}$ states that in the cartesian concept, nature is seen as passive, uniform, mechanical, separated from humans, and created to be dominated and exploited by humans. Women are a party that is weak and powerless to fight against the domination that exists. The domination model that tends to see women are weak is a model in Western capitalism that they always try to gain maximum profit in their daily lives. Like the movie industry, industrial interest also takes away the role and function of women and nature as represented by David's character, who does pornography against women for his movie project named Random Samples.

The video shooting contains pornography that Shiva and Mies said as the relation of passion and violence and fantasy and wishes that introduce women with parts of women's bodies that create porn sight. Shiva and Mies ${ }^{[18]}$ declares that Porn sight became the source of economic development in the advertisement, which is very commercial with the coming of many magazines, televisions, videos, movies, etc.. Capitalist patriarchy takes advantage of porn sight to make a commercial benefit. Besides, it reflects that human loose, feminine principle in themselves so that do all the things to make a profit.

On the other hand, David's character in Surfacing novel that record his wife naked by using camera shows us that Atwood highlights that the participation technology makes a gap between human and nature. The development of knowledge exploits humans, especially women, which Shiva and Mies stated are the party that is benefitted by the knowledge. Through narrative of narrator, Atwood ${ }^{[5]}$ states that camera is a tool which takes a human's soul : 
“..., at that time I was afraid, there was a machine that could make people vanish like that too, go nowhere, like a camera that could steal not only your soul but your body also."

The quotation above also shows that modern knowledge represented by the camera is reductionist and mechanical. It tries to conquer and reduct women's capacities in the productivity aspect, and besides that, it has dichotomized the relationship between humans and nature. Nature is no longer treated as a feminine principle called Prakriti, representing all the things in this world, and is treated as subordinate and exploited and oppressed. The camera is a symbol of modern knowledge that oppresses women and nature. Besides that, Tong ${ }^{[24}$ the violence against women in the form of pornography experienced by Anna character separates women and nature from men and culture. That separation hurts and exploits both women and nature.

The dead heron represents nature. Capitalist patriarchy shows their miss to nature in the wrong way. Atwood ${ }^{[6]}$ shows that capitalist patriarchy exploited dead heron for commercial profit instead of showing care and affection by burying it, as seen in this quotation :

"Heavy," David said. "What is it?"

"A dead bird," Anna said. She held her nose with two fingers.

$\cdots$

"We need that," David said, "we can put it next to the fish guts."

"Shit, "Joe said, "it really stinks."

"That will not show in the movie," David said, "you can stand it for five minutes; it looks so great, you have to admit."

I saw a beetle on it, blue-black and oval; when the camera whirred, it burrowed in under the feathers. Carrion beetle, death beetle. Why had they strong it up like a lynch victim? Why didn't they just throw it away like the trash? To prove they could do it, they had the power to kill ... It must have been the Americans, we would meet them"

The way they treat the dead heron shows that capitalist patriarchy only cares about their existence as humans or called anthropocentrism, and they think that they are separate from nature. Besides that, they do not show any affection and care toward nature. They refuse the fact that they are actually part of nature and should live harmoniously with nature.

\section{Maldevelopment and Illegal Logging for Industrial Sector}

Surfacing is a novel that denies maldevelopment carried out by capitalist patriarchy toward Canada's environment. It describes the change of natural ecosystem in Northern Quebec. Atwood uses Paul to expose maldevelopment in the tourism sector. Paul is a friend of the narrator's father, who wishes to change the cabin into a retreat lodge organized to make tourists come. Atwood ${ }^{[7]}$ describes the narrator disagrees with the wish.

"I believe I can speak for the rest of Michigan members in saying we'd be prepared to make you an offer."
"What for?" I said. He sounded as though he wanted me to buy something, a magazine or a membership.

He swept his pipe in a semi-circle. "This lovely piece of property," he said. "What we'd use it for would be a kind of retreat lodge, where the members could meditate and observe," he puffed, "the beauties of nature. And maybe do a little hunting and fishing. [----] "Well, we'd have to install a power generator, of course, and a septic tank; but apart from that, no, I expect we'd like to leave it the way it is, it has definite," he stroke his mustache, "rural charm"

The maldevelopment made for the tourism industry will interest many tourists in coming to that area. Besides human invasion, there will be a technology invasion that will harm the safeties of that area. The maldevelopment described is attended by some industries, such as hydroelectricity, entertainment, and tourism. The participation of those industries makes nature becomes the object of exploitation. Those industries act as patriarchy capitalist who ignores the sustainability of the object that they exploit. Besides, the development of a retreat lodge is a form of aggression of the corporation to the environment. According to Shiva and Mies [20], aggression toward the environment mostly physically can be felt as aggression toward femininity.

Hunting, fishing, and benefiting from rural persona is a sort of exploitation held by capitalist patriarchy shown in Surfacing. Hunting, fishing, and tourism in the remote area in Northern Quebec have potencies to make nature worse, and the ecosystem of nature becomes disturbed. Birds will be the object of hunting. Fish will be the target of fishing, so their population will be extinct as time goes. In this case, people treated nature as if it is in a lower position than humans by the capitalist patriarchy because of anthropocentrism that they carried out. Nature is seen as an economic commercialization object and adds capital accumulation by capitalist patriarchy.

Besides maldevelopment, there is also an illegal logging issue in Surfacing novel that is described by Atwood ${ }^{[8]}$, as following :

"Chainsaw, I could see them now, two men in yellow helmets. They'd left a trail, trees felled at intervals into the bay, trunks cut cleanly as though by a knife. Surveyors, the paper company or the government, the power company. If it was the power company I knew what it meant: they were going to raise lake level as they had sixty years ago, they were plotting the new shoreline. Twenty feet up again and this time they wouldn't cut off the trees as they had before, it would cost too much, they would be left to rot. The garden would go but the cabin would survive; the hill would become an eroding sand island surrounded by dead trees."

Atwood $^{[8]}$ also states another illegal logging for the pulp industry is also important to note.

"The first smell is the mill, sawdust, there are mounds of it in the yard with the stacked timber slabs. The pulpwood goes elsewhere to the paper mill, but the bigger logs are corralled in a boom 
on the river, a ring of logs chained together with the free ones nudging each other inside it; they travel to the saws in a clanking overhead chute, that hasn 't been changed"

Illegal logging is such of nature's exploitation that is conducted by capitalist patriarchy. They think that nature's exploitation as usual and natural thing and see both of nature and women as object and as 'the other' whereas Shiva ${ }^{[23]}$ stated that in masculine society, the domination of men toward women and nature make them see women and nature as 'the other,' the passive non-self'. Besides, nature is not treated as 'mother earth' or sacred soil but as an object for commercial interest.

Shiva and Mies ${ }^{[21]}$ states that forest is a part of nature for women and is a source of food for their lifetime, and keep the existence of biodiversity is very important for the use of forest in a feminine way. Besides that, Shiva ${ }^{[15]}$ also states that forest is the source of life and manages life in the soil, air, and local people.

\section{CONCLUSIONS}

Thus, the exploitation of women and the ecological crisis in the novel Surfacing by Margaret Atwood looks at two major things: the reduction of the womb of women with the presence of modern science and the exploitation of women and nature for the benefit of various industries by capitalist patriarchy. Nature and women are like being treated as objects or 'Others' exploited for humans' benefit. Animals and plants are no exception, being exploited negatively by being shot and then hung like a cross, and trees are cut down for the benefit of the paper and electricity industries. Men also consider themselves to have dominance over women and instead utilize women's bodies to benefit. The dualism of men/women and humans/nature that has been explained by Atwood in Surfacing with the hope that readers can realize the exploitation of nature and women has violated the feminine principle of 'Prakriti' which invites humans, both men, and women, to live side by side with nature and end the domination of the patriarchal and oppressive capitalist patriarchal society.

\section{REFERENCES}

[1] Atwood, M. Surfacing. U.S.A: General Paperbacks, 1983.

[2] Ibid, 85-86

[3] Ibid, 85

[4] Ibid, 144

[5] Ibid, 127

[6] Ibid, 125-126

[7] Ibid, 101-102

[8] Ibid, 122

[9] Ibid, 12

[10] Bhalla, A. Ecofeminism in Margaret Atwood's Surfacing. International Journal of Scientific and Research Publications, 2012, 2(10).

[11] Khan, Y.The Power and Promise of Ecofeminism: A Study of the Selected Novels of Margaret Atwood and Alice Walker. University of Kashmir, 2014.

[12] Koukhaei, Z., \& Afrougheh, S. New Perspective in Women and Nature: Dualism in Margaret Atwood's Surfacing. International Research Journal of Applied and Basic Sciences, 2013, 4(11).

[13] Monika, S. (2016). Surfacing: A Story about The Suppressed Condition of Women and Nature. International Journal of English Research, 2, 13-16.

[14] Shiva, V. Staying Alive: Women, Ecology, and Development. India: Kali For Women, 1988, 39

[15] Ibid, 74
[16] Shiva, V., \& Mies, M. Ecofeminism: Perspektif Gerakan Perempuan dan Lingkungan. Yogyakarta: IRE Press Yogyakarta, 2005, 17

[17] Ibid, 32

[18] Ibid, 216

[19] Ibid, 156

[20] Ibid, 15

[21] Ibid, 83

[22] Shiva, V. (1997). Bebas dari Pembangunan: Perempuan, Ekologi dan Perjuangan Hidup di India; penerjemah: Hira Jhamtani. Jakarta: Yayasan Obor Indonesia bekerja sama dengan KONPHALINDO, 93.

[23] Ibid, 5

[24] Tong, R. P. Feminist Thought: Pengantar Paling Komprehensif Kepada Arus Utama Pemikiran Feminis. Yogyakarta: Jalasutra, 2004, 385 . 